\title{
IEA's International Civic and Citizenship Education Study and the Teaching of Civic Education in Italy
}

\author{
Laura Palmerio, Valeria Damiani, and Elisa Caponera
}

\begin{abstract}
In this chapter, the results of Italy in the IEA International Civic and Citizenship Education Studies (ICCS) are briefly presented, highlighting the marginal role that civic education plays in educational policies and school practices in the Italian educational context. In Italy, although there was no specific teaching related to civic and citizenship education until 2020, the ICCS results have consistently been above the international average. Different hypotheses are proposed to explain these positive student outcomes. Two Italian experts in this field were interviewed; they agreed on the gap between the results of international surveys and their interpretations. They are of the opinion that some changes in educational policies in Italy would be valuable. INVALSI, the Italian institution responsible for the organization of ICCS, made a great effort to disseminate the results of the international surveys. Studies based on secondary analyses conducted on ICCS 2009 and 2016 are also described.
\end{abstract}

\section{Introduction}

Italy has participated in all International Association for the Evaluation of Educational Achievement (IEA) subject studies and is one of the very few countries that has participated in all IEA civic and citizenship education (CCE) surveys since the Six Subject Survey (1971). Considering the results across IEA cycles, three important aspects emerge regarding Italy: first, Italy's consistent, above-average international position in civic knowledge; second, some changes over time in attitudes and behaviors, some of which are negative; and third, the significant geographical gaps in civic knowledge and attitudes between northern and southern areas.

The authors of this chapter have overseen the organization and national coordination of the International Civic and Citizenship Education Study (ICCS) since 2013. They have also committed themselves to expand the relevance of the ICCS research theme by providing schools, teachers, and researchers with diversified ICCS materials, such as the theoretical framework and a national report of the Italian main results; by organizing national meetings (described in the following paragraphs in detail); and by conducting secondary analyses on the ICCS data.

This chapter is based on several sources: the data derived from ICCS 2009 and 2016, the ICCS 2016 international report (Schulz et al. 2018), the ICCS 2016 national report (Palmerio and Caponera 2018), interviews with experts in the field of CCE, national and international publications based on ICCS secondary analyses relevant to the Italian school system, and information retrieved from the Ministry of Education and other relevant national agencies. Below, the most significant results for Italy are presented (Table 1).

Laura Palmerio, INVALSI (National Institute for Educational Evaluation), Rome, Italy email: laura.palmerio@invalsi.it

Valeria Damiani, Lumsa Università, Rome, Italy

email: v.damiani2@lumsa.it

Elisa Caponera, INVALSI (National Institute for Educational Evaluation), Rome, Italy email: elisa.caponera@invalsi.it

(C) IEA International Association for the Evaluation of Educational Achievement 2021

B. Malak-Minkiewicz and J. Torney-Purta (eds.), Influences of the IEA Civic

and Citizenship Education Studies, https://doi.org/10.1007/978-3-030-71102-3_8 
Table 1: International and Italian mean scores in IEA's civic education studies

\begin{tabular}{l|c|c|c|c}
\hline \multirow{2}{*}{} & \multicolumn{2}{|c|}{ Italy } & \multicolumn{2}{c}{ International mean } \\
\cline { 2 - 5 } & Mean (s.e.) & Mean age & Mean (s.e.) & Mean age \\
\hline Civic Education Survey (1971) & 22.9 & 14.5 & 24.5 & 14.5 \\
\hline CIVED 1999 & $105(0.8)$ & 15.0 & $100(0.2)$ & 14.7 \\
\hline ICCS 2009 & $531(3.3)$ & 13.8 & $500(0.0)$ & 14.4 \\
\hline ICCS 2016 & $524(2.4)$ & 13.8 & $517(0.7)$ & 14.4 \\
\hline
\end{tabular}

Regarding civic knowledge, apart from the 1971 survey, Italy has always achieved scores above the international average and this result is consistent across adjacent cycles: ICCS 2016 vs ICCS 2009 and ICCS 2009 vs CIVED 1999.

For ICCS 2016, Italian students achieved a mean score of 524, which was above the international average (517). In 2009, Italy also performed better than the international mean (Italy 531 vs international mean 500). Even in the Civic Education Study (CIVED) 1999, Italian students performed above the international average (105 vs 100 as the international average). (TorneyPurta et al. 2001).

Female students outperformed their male counterparts in all the CIVED and ICCS cycles. Concerning the results related to students' attitudes, in 2016, Italian students reported that they talked with their parents about sociopolitical issues more frequently than in 2009 , but their trust in institutions had decreased over time. Moreover, compared to the international average, Italian students reported less favorable attitudes towards the rights of ethnic/racial groups and immigrants.

The Italian results in 2016 also evidenced substantial differences between geographic areas: northern students achieved higher performance results for civic knowledge than their southern counterparts, which was a similar result to that in 2009. However, compared to the national average, students from northern and central areas of the country showed less favorable attitudes both towards the rights of ethnic/racial groups and towards immigrants than southern students.

With regard to the national relevance of the IEA CCE surveys, it is worth mentioning the CIVED project, which was carried out in 1999. Additionally, as a national adaptation, students who participated in this study answered some cognitive items regarding political-institutional knowledge specific to the Italian context, such as the voting age in Italy, the requirements to be an Italian citizen, and the organization of Parliament. Two representative samples of grade 8 and 9 students were involved. The results were very disappointing, with more than $50 \%$ of the participating students knowing little about the Italian political system.

ICCS has influenced other national surveys on CCE; for example, the ICCS framework was used in 2018 by Alma Diploma, a national association that offers secondary school assessment tools and orientation for graduates, to conduct a national survey profiling upper secondary school graduates. Through the analysis of a student questionnaire that was administered at the end of secondary school, the following information was collected to construct students' profiles: social origin, academic success, evaluation of the school experience, extracurricular activities, linguistic knowledge, computer skills, academic and occupational expectations, strengths, and career orientation. The survey analyzed the characteristics and performance of secondary school graduates. Schools' participation in the project was voluntary, and although the results could not be considered representative of the Italian population, more than 40,000 students attending 292 upper secondary schools were involved. For the first time, in the sixteenth edition of the study, the questionnaire included questions regarding the subject of citizenship and the constitution. This, as mentioned above, was based substantially on the ICCS framework. The vast majority 
of graduates said their teachers had addressed citizenship and constitution topics during their lessons, namely, the Italian Constitution, European citizenship, human rights, intercultural dialogue, law-related education, and environmental education. Most students reported that human rights (83\%) and law related education (80\%) were useful, while environmental education and European citizenship were considered useful by $74 \%$ and $70 \%$ of students, respectively. These results largely confirm the cross-national analysis of the ICCS data collected about the aims of civic education from teachers in 2009 and reanalyzed by Reichert and Torney-Purta (2019). They found that Italian teachers emphasized imparting knowledge (on topics similar to these) and to a somewhat lesser extent encouraging students' independent thinking.

\section{Civic and Citizenship Education in the Italian School System}

In Italy, discussions of the relevance of CCE in the national educational system have regularly returned to the forefront.

Civic education was introduced as a curricular subject in 1958 by Aldo Moro (then the Italian Prime Minister). Although it was considered a separate subject, it was taught for only two hours per month, involved no formal assessment, and was integrated into the history curriculum.

In the following decades, civic education was not considered a separate subject and played a marginal role in educational policies and school practices. In primary school programs in 1985, civic education was defined as "education for democratic coexistence" (educazione alla convivenza democratica) and was integrated into the social studies curriculum.

Following changes in Europe and internationally (e.g., the fall of the Soviet Bloc, globalization, the Maastricht treaties), in 1996 the ministry proposed to include a curriculum of civic education and constitutional culture that would be integrated into all subjects. This proposal has never been enforced because of the fall of the government (and subsequent governments did not support it).

Within the framework of the reform of the education system (the so-called "Moratti reform" from the name of the Minister of Education) in 2003, "education about the fundamental principles of civil coexistence" (convivenza civile) became one of the objectives of schools at all levels. In the national guidelines, the teaching of civil coexistence was then structured into six areas of education: citizenship education, road safety education, environmental education, food and nutrition education, health education, and affective education. The implementation of these guidelines, which have changed several times, has never been regulated; the guidelines were later superseded by new ones for the curriculum for the first cycle of education (for children aged 3 to 14-years-old, i.e., pre-primary, primary, and lower secondary students).In the annex to the Ministerial Decree of August 22, 2007, no. 139, ("Regulations containing rules on the fulfilment of the education obligation"), following the international and European debate on key competences, the Ministry indicated that "key competences of citizenship are to be acquired at the end of compulsory education."

In 2008, an educational bill proposed a new subject, citizenship and constitution, to be taught at all school levels, with a time allocation of 33 hours per year and with the aim of ensuring that students acquire "the knowledge and skills related to peaceful coexistence and citizenship" (MIUR 2008). The inclusion of this new subject in the curriculum was associated with the need to fight the increasingly widespread phenomena of bullying in schools, and combined with the introduction of a specific grade to be given for students' behavior. There was a reaction to a political context that was strongly critical of the general permissive culture in society (a legacy of the 1968 movement). This was thought to have a negative effect on students' knowledge and behaviors. Therefore, the introduction of the citizenship and constitution subject to the curriculum was viewed by some researchers as a restoration and a cultural process in line with the traditional ideas of the center-right party (Losito 2009). 
However, in the subsequent law, generic projects and support for schools and teachers replaced the introduction of the new subject that was to be taught within the history/geography and society/history subject areas for all educational cycles during the 2009/2010 school year, and no reference to a specific time allocation (as initially proposed) was included. In 2009, the "Guidance document for the pilot of the teaching of 'Citizenship and Constitution'" ["Documento d'indirizzo per la sperimentazione dell'insegnamento di 'Cittadinanza e Costituzione'"] was published, aimed at identifying ways to implement this new curricular subject in schools and defining its objectives (Prot. 2079, March 4, 2009).

Nevertheless, the guidelines included in the document presented some contradictions between certain values and competences to be developed in students and did not resolve the thorny issue related to assessment. The document was mainly focused on transversal or cross-curricular competences but, at the same time, asked teachers of CCE-related subjects to implement traditional assessment practices. Finally, the document provided schools with the autonomy to recommend and trial the organizational solutions, teaching and assessment practices that would be most effective for the teaching of citizenship and constitution. However, this choice, together with the chronic lack of funding for the education sector in Italy, was one of the most important factors that led to the substantial failure of the trials (Losito, 2009).

In 2010, the idea of considering citizenship and constitution an independent subject was abandoned. The subject would have been characterized by two complementary approaches: an integrated approach (within the history/geography and history/society subject areas) and a crosscurricular approach (involving all the disciplines of the course of study). These two approaches were supplemented by a third approach, which concerned extracurricular projects.

The initial trial for the teaching of citizenship and constitution, promoted by the Ministry of Education in 2010, was therefore limited to the implementation of innovative projects related to the area of citizenship and constitution. The funding was assigned to projects related to "an effective and innovative way" of delving into the Constitution and its principles "with the priority need to design and implement active citizenship initiatives" (decree no. 114 of May 27, 2009). The bodies responsible for the support, monitoring, and evaluation of the educational projects were identified as the ANSAS (National Agency for School Autonomy Development) regional units and the Regional School Offices (with the collaboration of Istituto nazionale per la valutazione del sistema educativo di istruzione e di formazione [INVALSI]).

Another series of projects related to the subject of citizenship, constitution, and security was initiated in the 2011/2012 school year by the Ministry of Education, National Institute for Insurance against Injuries at Work (INAIL), and the Ministry of Labor and Social Policies, in collaboration with ANSAS. Given the sources of funding, the objectives of the projects included thematic areas that ranged from citizenship education to avoiding accidents inside and outside the school community.

Since the school year 2015-2016, the Ministry of Education, in collaboration with the Italian Parliament, has promoted projects to support the teaching of citizenship and constitution across all school levels. These projects encompass diverse cross-curricular activities such as the investigation of the meaning and application of selected principles of the constitution in the local community, meetings and trainings at the Italian Senate, analysis of the effects of laws and regulations to encourage civic engagement in everyday life, initiatives related to human rights education, and meetings with members of the Parliament.

Apart from these projects and initiatives related to citizenship and constitution organized by the Ministry of Education in collaboration with the Parliament or other state bodies (e.g., the Ministry of Defense), citizenship education has also been present in lower secondary education curricula as a cross-curricular area in all subjects (to develop social and civic competences) and as a subject integrated with history and geography (to provide a disciplinary foundation). 
Social and civic competences are one of the eight key competences for lifelong learning that were identified in the Recommendation of the European Parliament and of the Council of December 18, 2006, a document that provided a foundation for the national guidelines for the curriculum of the first cycle of education (students age 3-14) (European Parliament and the Council 2006).

The section on citizenship and constitution stated that citizenship education was to be promoted "through meaningful experiences that allow us to take care of ourselves, others and the environment and that encourage forms of cooperation and solidarity" (Ministero dell'Istruzione, dell'Università e della Ricerca [MIUR] 2012, p. 25). The main objective was related to the knowledge of the Italian Constitution, with the general aim of fostering an ethic of responsibility and legality and of improving students' everyday life contexts, starting with the school.

Five years after the release of the national curricular guidelines, the document "Curricular guidelines and new scenarios" (MIUR 2018) stated that CCE should be the cornerstone for the promotion of all subjects across the curriculum in the first cycle of education, with a specific focus on global citizenship and sustainability. A draft law, passed in August 2019, referred to the teaching of civics and citizenship in the first and second cycles of education. It stipulated that civic education will be taught by teachers in the history/geography subject area in primary and lower secondary schools and by teachers in the economics/law area in upper secondary schools. The law states that there will be a civic education grade on students' report cards but no extra hours allotted to the subject at school. Therefore, each school and its board will have to allocate 33 hours per year to teach civic education, subtracting these hours from other subjects.

The civic education hours will cover the following topics: the Italian Constitution; the fundamental elements of law, especially in the field of labor law; the principles of the European Union and international law; digital citizenship education; eco-sustainable development and environmental education; preservation of Italian historical-artistic heritage; and, education about laws. As part of the teaching of civic education, in partnership with the local community, the following topics will also be addressed: road safety education, the right to health and well-being, and volunteering and active citizenship education.

In summary, from an educational policy perspective, on the one hand, educational authorities have often expressed support, identified a wide range of possible topics, carried out initiatives on CCE during the years, and continued to participate in international projects on the subject (i.e., the IEA surveys on CCE). On the other hand, however, they have never been committed to developing the organizational conditions (in terms of a coherent curriculum, assessments, teachers' training) that could actually make the declarations of principles feasible in practice. This is a limitation that characterizes the educational policies in Italy as a whole and not only about CCE.

\section{Civic and Citizenship Education Teachers}

As indicated in the Eurydice report Citizenship Education at School in Europe (2017), there are continuing professional development opportunities for teachers in the area of citizenship education. Nonetheless, in Italy, there are no specific requirements for teachers who teach courses related to civics and citizenship. In both primary and lower secondary schools, CCE is taught by Italian language, history, and geography teachers (in other words, teachers with a degree in the humanities), and in upper secondary schools, CCE is taught by the teachers qualified to teach legal and economic disciplines, when available.

Since the 2008-2009 school year, actions have been taken to raise awareness and implement teacher training in skills related to citizenship and constitution in the history/geography and history/society subject areas in primary, and lower and upper secondary education. For example, in 
the 2009-2010 school year, the University of Padua and the Veneto Region promoted "advanced training courses in civic education, human rights, citizenship, and the Constitution" for teachers. ${ }^{1}$

Moreover, the Interdepartmental Centre for Research and Services on the Rights of the Individual and People of the University of Padua, in partnership with the Ministry of Education and the ANSAS, initiated the project Citizenship and Constitution: Learning the European Union at School (2012). The specific objective of the project was twofold: 1) to form a group of teacher-tutors from all Italian regions on the theme of human rights and active citizenship in the European Union and 2) to develop a training course for teaching about the European Union at school. These objectives were framed as an integral part of the teaching of citizenship and constitution. More specifically, the project aimed to organize two national training seminars for 40 teachers selected by each Regional Education Authority among teachers at all school grades who already had basic preparation in the process of European integration and human rights through national seminars or related initiatives promoted by the Ministry of Education.

This initiative is linked to diverse teacher training and professional development courses related to CCE that have been implemented over the years by different associations and organizations; some of them are recognized by the Ministry of Education, while some are not. Each teacher is free to choose whether and which one to attend. Since the courses are not compulsory, it is not possible to estimate the number of teachers that take them. Opportunities for in-service and preservice teacher training related to CCE at the regional and national levels are variable and are often considered insufficient. In 2014, an online public consultation. was held by the Minister of Education, in which more than 1,800,000 teachers, students, and families participated. Among the various results, the consultation showed that a significant proportion of people strongly suggested that the teaching and learning of civic and citizenship issues should be enhanced (especially in terms of active citizenship, environmental education, and emotional and sexual education).

\section{Influences of ICCS on Political Debates and Education Research}

\section{Influences of ICCS on Political Debates}

In Italy, there is a general weakness in the interconnections between research and policies in the fields of education or schooling and the consequent implementation of reforms at various levels; the implementation of reforms involves little or no consideration of research results, including those from large-scale surveys. Therefore, describing the impact of ICCS on policy debates and education research is not an easy task. For this reason, to explore the influence of ICCS on political debates in Italy, we interviewed two key figures in the field of CCE who have been involved in political initiatives at the national level and conducted extended research at the international level: Luciano Corradini and Bruno Losito.

Luciano Corradini, professor emeritus of Education at Roma Tre University, was president of the Regional Institute for Educational Research (IRRSAE) in the Lombardy Region for 11 years (1979-1990), vice president of the National Council of the Ministry of Education (1989-1997), and undersecretary of the Ministry of Education (1995-1996). During his year and a half as the undersecretary at the Ministry of Education, he was the chair of the civic education commission, whose aim was to develop a curriculum on civic education and constitutional culture.

Bruno Losito, full professor of Foundations of Educational Research and Research Methods at Roma Tre University, has been on the International Advisory Committee for the second IEA study on civic education (CIVED) since the 1990s, served as a national research coordinator for IEA CIVED 1999 and served as an associate research director for ICCS 2009 and 2016 as well

1 https://unipd-centrodirittiumani.it/it/collaborazioni/Corsi-di-Alta-Formazione-per-esperti-in-Educazione-civicadiritti-umani-cittadinanza-costituzione/225 
as for the upcoming 2022 study. At the national level, he was a member of a civic education commission of the Ministry of Education.

The interviewees have taken an active part in the academic debate on CCE at the national level, developing different approaches to the delivery of CCE in Italy. Corradini supports civic education being treated as a separate subject across Italian school curricula, with its own time schedule and assessment; Losito is in favor of an integrated and cross-curricular approach to CCE that designates teachers as responsible for the delivery of CCE at the school level.

In Corradini's view, the need to introduce a separate subject is intertwined with the need to guarantee a dedicated status for civic education, a relevance that otherwise cannot be recognized for this area in relation to other subjects in the curriculum. His approach is in line with the organization of schools in Italy, where often the elements of civic education are included in other subjects in the curriculum (e.g., within history and geography), while citizenship education is usually related to wider aspects of school life.

On the other hand, in the integrated and cross-curricular approach to CCE that Losito suggests, the teachers who are responsible for CCE (coordinators) play an important role in managing the particular contributions that every subject and the school as a whole can bring to CCE. This includes participation opportunities inside schools and the development of an open and respectful classroom and school climate, which all of the IEA civic education studies have identified to be important. The CCE coordinator also focuses on group work at the school level, which often requires a reconsideration of the usual educational organization in Italian schools, where teachers find it difficult to modify rigid schedules and organize the time for collective work. Both approaches present strengths and weaknesses that (still) need to be tested through extensive pilot programs and trials across the nation that could be implemented by educational authorities as well as by single schools.

Although Losito and Corradini have developed different conceptualizations of CCE that represent two possible approaches to deliver CCE within the Italian curricula and school system, they both agree on the existing gap between the findings of international surveys and the consideration of the implications for educational policies in Italy. Italian policymaking processes for education are generally characterized by a weak association between large-scale assessment and educational research more generally. This is especially true if we consider the studies promoted by IEA, which have gained attention mainly from academic researchers in Italy.

In contrast, the Organisation for Economic Co-operation and Development (OECD) Programme for International Student Assessment (PISA) results have raised considerable interest among policymakers, given the interest that national and European governments often show to the relationship between students' competencies included in this survey and economic development (Pizmony-Levy and Torney-Purta 2018). Nevertheless, research has found no direct, clear influences of PISA on the school system in Italy and has highlighted only an indirect effect of these OECD surveys on policies in education. This indirect effect is related to educational initiatives carried out at local levels (especially in some areas of southern Italy, where many students have performed poorly on PISA) and in the improvement of the national system for student assessment (Hopkins et al. 2008; Breakspear 2012; Damiani 2016).

In agreeing about the low impact of ICCS, as well as other IEA large-scale assessments, on educational policies in Italy, the interviewees stressed the role that the study has nevertheless played in national debates, especially regarding the theoretical assumptions underpinning the conceptualizations of CCE. This role must be considered in close connection with the work of other international bodies that have addressed the topic (e.g., the Council of Europe and the European Union). While Corradini stressed the relevance of the Eurydice reports on CCE to the Italian debate, Losito highlighted the mutual connections among the initiatives of the Council 
of Europe and the European Union and the results of the IEA surveys in developing the idea of CCE in terms of its characteristics, approaches, and delivery in schools.

In addition, according to Losito, another relevant contribution of ICCS at the national level is related to the measurement and assessment of students' outcomes in CCE. These studies provide theoretical frameworks along with data and indicators of the ways that schools prepare young people to become citizens. In fact, ICCS is the only study that offers international comparative data and indicators in this subject area. Thus, the influence of ICCS can also be recognized in the increased secondary analyses, which have contributed to the investigation of CCE in Italy (see next section).

\section{The Role of INVALSI in Promoting ICCS and Influences on the Education Debate}

INVALSI is responsible for the organization, management, and implementation of the Italian component of the main international surveys promoted by IEA and the OECD, thus ensuring Italy's participation in these studies. INVALSI has made substantial efforts to disseminate the results from international surveys by organizing public events, supporting schools and teachers, and conducting analyses on the surveys' data.

To reach a large number of researchers, teachers, and people in general who could be interested in the topic, the ICCS 2009 framework was translated into Italian, and it can be downloaded from the INVALSI website. In 2011, a public event was organized by INVALSI to present the Italian results of ICCS 2009, with the participation of many stakeholders at the school level (principals, teachers, educational researchers, etc.); unfortunately, no policymakers took part in the event. Again, in 2017, on the same day as the release of the international results, INVALSI organized a public seminar where the Italian results of ICCS 2016 were presented with international comparisons. The focus was on the ICCS 2016 main results, such as students' knowledge, participation, and attitudes, as well as on the ICCS European Student Questionnaire. For this seminar, INVALSI invited Italian experts to speak about current CCE issues and challenges and invited teachers and students from different grades to report on their school experiences and activities related to CCE. Moreover, an expert from the Laboratorio di Pedagogia Sperimentale (LPS) at Rome Tre University, which is part of the international consortium running ICCS, described the Italian results for the European Student Questionnaire. The press was invited to the seminar, and a summary of the results was shared with the media. The research findings were released in national newspapers, on some newscasts, and on some websites that focus on educational debates (e.g. De Gregorio, 2017; Imperato, 2017; Marcello, 2017; Moriggi, 2017).

In early 2018, the ICCS 2016 national report (Palmerio and Caponera 2018) was published on the institutional website. The report presented the results at the national level and compared them with the international results and with the results within Italy, showing significant differences between geographical areas.

All the schools that participated in the ICCS 2016 data collection received an email message with a link to the national report. Moreover, INVALSI provided each school with their specific results and a comparison of their results with the national and territorial benchmarks. The ICCS 2016 national report is also going to be uploaded to the National Statistical System (SISTAN) website.

INVALSI annually prepares a report for the Parliament based on the information from the international surveys as well as the national assessment: in 2018 a detailed report was prepared on the ICCS 2016 results, which were particularly relevant for the Italian school system.

In recent years, analyses conducted on the ICCS data, as well as analyses of other international surveys, have contributed to building a committed community of researchers in this area. These efforts have led to some relevant publications both at national and international levels based on secondary analyses conducted on the ICCS 2009 and 2016 data (reviewed by Knowles et al. 2018). Some of these are briefly mentioned below. 
Alivernini and Manganelli (2011), using the Italian data from ICCS 2009, found that students' civic knowledge scores were significantly higher if their schools provided an open classroom climate for discussion. Manganelli et al. (2012) found a positive significant relationship between openness in classroom discussion and the valuing of students' participation (school level) with students' civic knowledge and political efficacy (student level), on the one hand, and students expected political participation, on the other hand.

In 2014, a case study was carried out in all of the eight lower secondary schools from the city of Foggia (a town in the region of Puglia in southern Italy). that participated in ICCS 2009. The author based the research design on the ICCS 2009 framework and administered the ICCS 2009 questionnaires to students, teachers, and school principals. She found a positive association between students' participation in civic activities and the frequency of their discussions on political and social topics with parents and friends (Zappatore 2016).

Paletta (2014) published an article on the effect of school autonomy, measured through the ICCS school questionnaire, on multiple measures of student achievement, combining the individual data of the students participating in the ICCS survey with their results on the national highstakes standardized tests administered by INVALSI at the end of grade 8 . In general, the results highlighted that autonomy was a prerequisite for implementing several institutional changes (outside schools) and organizational changes (internal to each school) that appeared to lead to some improvement in student achievement.

Azzolini (2016), using data from students who participated in both ICCS 2009 and the Italian national assessment and controlling for socioeconomic background and cognitive achievement test scores, did not find a migration-specific gap in civic development. Furthermore, perceptions of fairness in student-teacher interactions was found to improve students' civic development, confirming that the school climate plays a vital role in enhancing children's civic knowledge. For further reflection on this topic see Reichert et al. (2018).

In 2018, the book Becoming European citizens. Ideas, tools and resources for a conscious education to Europe (Corbucci and Freddano 2018) was published to advance the knowledge about education on European citizenship. The book is mainly addressed to those who work in schools, such as principals and teachers, and offers proposals for learning activities, especially for secondary school (from grade 6 to grade 13). The book also contains two chapters related to the ICCS 2009 results. These chapters consider the following topics:

- The Italian results in the European Module: This chapter is focused on cognitive test scores and the ICCS 2009 questions about attitudes towards Europe and compares them with those of the other European countries participating in the survey (Caponera and Palmerio 2018);

- Students' perceptions of multiple identities, their attitudes towards European institutions and their trust in national, European, and supranational entities: The results show that most students consider themselves to be Europeans and hold positive attitudes towards the European Union and international organizations (Damiani 2018).

An agreement has recently been signed between the Italian National Institute of Statistics (ISTAT) and INVALSI under which INVALSI will provide ISTAT-one of the main points of reference for any researcher intending to do secondary analyses-with Italy's ICCS 2016 database, as well as the other international survey's databases. Recently, INVALSI made it possible to match the ICCS data-as well as those of other international surveys - with national assessment data (carried out every year in all schools, in several grades including grade 8). This will allow analyses of students' ICCS knowledge and questionnaire data in relation to other relevant variables, such as mathematics and language test results and other information derived from the context questionnaire administered during the national assessments. This is beginning to encourage researchers to use these data in their research. 


\section{Summary and Conclusions}

- Italy is one of the very few countries participating in all the IEA CCE tests and surveys since the Six Subject Survey (1971).

- Across IEA cycles, no substantial differences were found regarding the civic knowledge levels of students; they performed slightly above the international mean in each study. However, shifts in civic attitudes and anticipated behaviors have occurred, some in a negative direction, such as trust in civic-related institutions.

- Geographic gaps persist: students from northern and central areas have less favorable attitudes towards the rights of ethnic/racial groups and immigrants than students from southern areas. Moreover, northern students outperform southern students in civic knowledge.

- Civic education has played a marginal role in directly influencing educational policies and school practices in the Italian educational context. However, recently, a draft law that proposed introducing CCE as a separate school subject was approved.

- Currently, in Italy, there are no specific requirements for teachers to teach courses related to CCE. CCE is taught by Italian language, history, and geography teachers with degrees in the humanities.

- Two experts in this field were interviewed (Luciano Corradini and Bruno Losito), and they both agreed on the existing gap between international survey findings and the implications and educational policies proposed in Italy.

- INVALSI is responsible for the organization, management, and implementation of the Italian component of international surveys, and it has been making a great effort to disseminate the results of international surveys. Among other initiatives, INVALSI organized a public seminar in which the Italian results of ICCS 2016 were presented, and a summary of the results was shared with the media. In early 2018, the ICCS 2016 national report was published on the institutional website.

- In recent years, analyses of the ICCS data, as well as those of other international surveys, have contributed to building a committed community of researchers. This has led to relevant publications at both the national and international levels based on the secondary analyses conducted on ICCS 2009 and 2016.

\section{References}

Alivernini, F., \& Manganelli, S. (2011). Is there a relationship between openness in classroom discussion and students' knowledge in civic and citizenship education? Procedia-Social and Behavioral Sciences, 15, 3441-3445.

Azzolini, D. (2016). Investigating the link between migration and civicness in Italy. Which individual and school factors matter? Journal of Youth Studies, 19(8), 1022-1042.

Breakspear, S. (2012). The policy impact of PISA: An exploration of the normative effects of international benchmarking in school system performance. OECD Education Working Papers, No. 71. OECD Publishing (NJ1). http://dx.doi.org/10.1787/5k9fdfaffr28-en.

Caponera, E., \& Palmerio, L. (2018). Valutare le competenze di cittadinanza: I'indagine IEA ICCS e il modulo europeo. In A. Corbucci, \& M. Freddano (2018), Diventare cittadini europei. Idee, strumenti e risorse per un'educazione consapevole all'Europa (pp. 171-188). I Quaderni della ricerca (39), Loescher Editore, Torino.

Corbucci, A., \& Freddano, M. (2018). Diventare cittadini europei. Idee, strumenti e risorse per un'educazione consapevole all'Europa [Becoming European citizens. Ideas, tools and resources for a conscious education to Europe]. I Quaderni della ricerca (39), Loescher Editore, Torino.

Damiani, V. (2016). Large-scale assessments and educational policies in Italy. Research Papers in Education, 31(5), 529-541.

Damiani, V. (2018). Essere europei: uno studio sulla percezione delle identità multiple e sugli atteggiamenti verso I'Unione Europea degli studenti tredicenni. In A. Corbucci, \& M. Freddano (2018), Diventare cittadini europei. Idee, strumenti e risorse per un'educazione consapevole all'Europa (pp. 204-213). I Quaderni della ricerca (39), Loescher Editore, Torino. 
De Gregorio, A. (2017). INDAGINE IEA-ICCS 2016. Educazione civica: le ragazze battono i maschi. Figli più europei dei padri. Corriere della sera. https://www.corriere.it/scuola/medie/17_novembre_07/educazionecivica-ragazze-battono-maschi-figli-piu-europei-padri-57b1a41e-c396-11e7-8679-22cd098c4574.shtml European Commission/EACEA/Eurydice. (2017). Citizenship education at school in Europe-2017. Eurydice Report. Brussel, Belgium: European Commission.

European Parliament and the Council. (2006). Recommendation of the European Parliament and of the Council of 18 December 2006 on key competences for lifelong learning. Official Journal of the European Union, L394/310, p. 13.

Hopkins, D., Pennock D., Ritzen J., Ahtaridou E., \& Zimmer, K. (2008). External Evaluation of the Policy Impact of PISA. OECD doc. EDU/PISA/GB(2008)35/REV1. Paris, France: OECD Publishing.

Imperato, M. (2017). II secondo ciclo della ricerca International Civic and Citizenship Education Study 2016 della IEA: le competenze degli studenti italiani. Rassegna dell'Autonomia Scolastica. http://www. autonomiascolastica.it/single.php?idNews $=1464$

Knowles, R., Torney-Purta, J., \& Barber, C. (2018). Enhancing citizenship learning with international comparative research: Analyses of IEA civic education datasets. Citizenship Teaching and Learning, 13, 7-30. http://www.ingentaconnect.com/content/intellect/ctl/2018/00000013/00000001/art00002

Losito, B. (2009). La costruzione delle competenze di cittadinanza a scuola: non basta una materia. Cadmo, 17(1), 99-112.

Manganelli, S., Alivernini, F., Lucidi, F., \& Di Leo, I. (2012). Expected political participation in Italy: a study based on Italian ICCS data. Procedia-Social and Behavioral Sciences, 46, 1476-1481.

Marcello, G. (2017). Educazione Civica, studenti italiani promossi. E le ragazze battono i maschi. Skuola.Net. https://www.skuola.net/news/inchiesta/educazione-civica-cittadinanza-studenti-iccs2016-invalsi.html

Ministero dell'Istruzione, dell'Università e della Ricerca. (2012). Indicazioni Nazionali per il curricolo della scuola dell'infanzia e del primo ciclo di istruzione. Periodico multimediale per la scuola italiana a cura del Ministero dell'Istruzione, dell'Università e della Ricerca, Anno LXXXVIII, Annali della Pubblica Istruzione. Numero Speciale 2012. http://www.indicazioninazionali.it/wp-content/uploads/2018/08/ Indicazioni_Annali_Definitivo.pdf

Ministero dell'Istruzione, dell'Università e della Ricerca. (2018). Indicazioni Nazionali e Nuovi Scenari. https://www.miur.gov.it/documents/20182/0/Indicazioni+nazionali+e+nuovi+scenari/3234ab16-1f1d4f34-99a3-319d892a40f2.

Moriggi, A. (2017). ICCS 2016: a lezione di cittadinanza. Radio Cusano Campus. https://www.tag24. it/192932-iccs-2016/

Paletta, A. (2014). Improving students' learning through school autonomy: Evidence from the international civic and citizenship survey. Journal of School Choice, 8(3), 381-409.

Palmerio, L., \& Caponera, E. (2018). Indagine IEA ICCS 2016: i risultati degli student italiani in Educazione Civica e alla cittadinanza. INVALSI. https://www.invalsi.it/invalsi/ri/iea-doc/iccs2016/Rapporto_ ICCS_2016_definitivo.pdf

Pizmony-Levy, O., \& Torney-Purta, J. (2018). How journalists and researchers communicate results of international large-scale assessments. CADMO, (1), 51-65.

Reichert, F., Chen, J., \& Torney-Purta, J. (2018). Profiles of adolescents' perceptions of democratic classroom climate and students' influence: The effect of school and community contexts. Journal of Youth and Adolescence, 47(1). https://doi.org/10.1007/s10964-018-0831-8.

Reichert, F., \& Torney-Purta, J. (2019). A cross-national comparison of teachers' beliefs about the aims of civic education in 12 countries: A person-centered analysis. Teaching and Teacher Education, 77, 112-125. https://doi.org/10.1016/j tate.2018.09.995.

Schulz, W., Ainley, J., Fraillon, J., Losito, B., Agrusti, G., \& Friedman, T. (2018). Becoming citizens in a changing world. IEA International Civic and Citizenship Education Study 2016 international report. Cham, Switzerland: Springer. https://doi.org/10.1007/978-3-319-73963-2

Torney-Purta, J., Lehmann, R., Oswald, H., \& Schulz, W. (2001). Citizenship and education in twenty-eight countries. Civic knowledge and engagement at age fourteen. Amsterdam, the Netherlands: International Association for the Evaluation of Educational Achievement (IEA). https://www.iea.nl/publications/studyreports/international-reports-iea-studies/citizenship-and-education-twenty-eight

Zappatore, T. (2016). Cittadinanza a scuola. Studio di caso: una ricerca tra e con I protagonisti della scuola. Foro de Educación, 14(20), 231-252. 
Open Access This chapter is licensed under the terms of the Creative Commons Attribution-NonCommercial 4.0 International License (http://creativecommons.org/licenses/by-nc/4.0/), which permits any noncommercial use, sharing, adaptation, distribution and reproduction in any medium or format, as long as you give appropriate credit to the original author(s) and the source, provide a link to the Creative Commons license and indicate if changes were made.

The images or other third party material in this chapter are included in the chapter's Creative Commons license, unless indicated otherwise in a credit line to the material. If material is not included in the chapter's Creative Commons license and your intended use is not permitted by statutory regulation or exceeds the permitted use, you will need to obtain permission directly from the copyright holder.

\section{(c) (1) \$}

